\title{
IMPLEMENTASI PENYULUHAN DIET SEHAT PRAKTIS DAN KUALITAS HIDUP ANAK PADA IBU-IBU DI WILAYAHPOSYANDU KENARI I
}

\author{
Gisely Vionalita \\ Fakultas Ilmu-ilmu Kesehatan, Universitas Esa Unggul, Jakarta \\ Jalan Arjuna Utara Nomor 9, Kebon Jeruk, Jakarta Barat - 11510 \\ gisely@esaunggul.ac.id
}

\begin{abstract}
The discovery of several problems related to the quality of life of children in the Kalideres Health Center, such as the number of diarrheaand skin diseases in children, then several problems in social and emotional abilities in children showed a low number of quality of life based on the physical, social, emotions and environment. Therefore, the importance of knowledge about the quality of life and the efforts that can be made in increasing the domain in each quality of life. In this community service outreach, the quality of life of children is accompanied by counseling on a practical healthy diet. This education explains the definition and importance of quality of life. Then explained the efforts to improve the quality of life of children and the importance of maintaining a healthy diet by eating healthy and nutritious foods. As a result of the Covid-19 pandemic, outreach was held in the form of leaflet media containing complete information about the quality of life and a practical healthy diet for children and distributed to mothers with children aged 6-12 years in the Kalideres Health Center Area. Additionally, it is included by carrying out a measure of knowledge after counseling which is then used the data to profile the knowledge of the quality of life of the patient. The results of measuring the quality of life knowledge were also found to increase from the average value that knows the definition of quality of life was obtained by $84 \%$, the definition and benefits of healthy food was $92 \%$ and the required food content was $88 \%$. This information is important to ensure parents understand the efforts that can be made to improve the quality of life for children and a healthy, practical diet for children.
\end{abstract}

Keywords: Quality of life, healthy diet food, children

\begin{abstract}
Abstrak
Ditemukannya beberapa masalah yang berkaitan dengan kualitas hidup anak yang terdapat di wilayah Puskesmas kalideres seperti, adanya angka diare, ISPA dan penyakit kulit pada anak kemudian beberapa permasalahan dalam sosial dan kemampuan emosi pada anak menunjukkan rendahnya angka kualitas hidup yang didasari dengan domain fisik, social, emosi dan lingkungan. Oleh karena itu pentingnya adanya pengetahuan mengenai kualitas hidup dan upaya yang dapat dilakukan dalam meningkatkan domain di setiap kualitas hidup tersebut. Dalam kegiatan pengabdian masyarakat ini kualitas hidup anak disertakan dengan penyuluhan mengenai diet sehat praktis.Penyuluhan ini menjelaskan mengenai definisi dan pentingnya kualitas hidup. Kemudian menjelaskan upaya untuk meningkatkan kualitas hidup anak dan pentingnya menjaga diet sehat dengan mengonsumsi makanan sehat dan bergizi.Akibat pandemic Covid-19 penyuluhan diadakan berupa penyuluhan dengan media leaflet yang berisi informasi lengkap mengenai kualitas hidup dan diet sehat praktis anak dan disebarkan ke ibu-ibu yang memiliki anak usia 6-12 tahun di Kawasan Puskesmas Kalideres. Penyuluhan juga disertakan dengan melaksanakan pengukuran pengetahuan sesudah penyuluhan yang kemudian digunakan datanya untuk memprofilkan pengetahuan kualitas hidup pasien. Hasil pengukuran pengetahuan kualitas hidup juga didapatkan meningkat dari nilai rata-rata yang mengetahui definisi kualitas hidup didapatkan sebanyak $84 \%$, definisi dan manfaat makanan sehat 92\% dan kandungan makanan yang dibutuhkan $88 \%$. Informasi ini penting untuk dapat memastikan orang tua memahami upaya yang dapat dilakukan untuk meningkatkan kualitas hidup anak dan diet sehat praktis untuk anak.
\end{abstract}

Kata kunci : Kualitas hidup anak, diet sehat, penyuluhan

\section{Pendahuluan}

Ditemukannya beberapa masalah yang berkaitan dengan kualitas hidup anak yang terdapat di wilayah Puskesmas kalideres seperti, adanya angka diare, ISPA dan penyakit kulit pada anak kemudian beberapa permasalahan dalam sosial dan kemampuan emosi pada anak menunjukkan rendahnya angka kualitas hidup yang didasari dengan domain fisik, social, emosi dan lingkungan. Munculnya beberapa masalah ini disebabkan oleh kurang pahamnya orang tua mengenai pentingnya kualitas hidup anak, untuk memastikan anak yang 
produktif dan sukses di masa yangakan datang. Kualitas hidup ini juga disertai dengan permasalahan perilaku diet anak tersebut. Perilaku makan makanan yang tidak bergizi, kurang sayur dan juga jajan sembarangan juga menjadi permasalahan yang terdapat di anak yang ada di wilayah Kalideres khususnya Posyandu Kenari 1. Hal ini yang dipercaya berhubungan juga dengan kualitas hidup anak.

Berdasarkan pernyataan kepala Posyandu Kenari 1 di kalideres, permasalahan yang paling banyak ditemukan adalah permasalahan yang berkaitan dengan habit orang tua yang membiarkan anak nya untuk mengonsumsi makanan yang tidak bergizi dengan alasan kepraktisan, dan membiarkan anaknya jajan sembarangan. Hal ini dikarenakan perekonomian di wilayah tersebut masih dipenuhi oleh ibu-ibu yang bekerja di sector informal, seperti berjualan, asisten rumah tangga dan masih didominasi oleh pendidikan yang rendah. Sehingga masih banyak anak yang dibiarkan tanpa diperhatikan perilaku diet dan kualitas fisik, sosial, emosi dan lingkungan yang mengindikasikan kualitas hidup anak tersebut. Selain itu Posyandu tidak memiliki alat untuk memantau langsung perilaku anak yang ada di wilayah tersebut.

Posyandu Kenari 1 ada di wilayah Puskesmas kalideres yang masih memiliki permasalahan di bagian sanitasi. Masih ada di wilayah tersebut yang berbatasan dengan sungai dan masih berupa wilayah kumuh. Mayoritas yang bekerja disana merupakan pekerja tidak tetap di sektor informal, seperti berjualan, buruh harian dan pekerjaan lainnya yang memiliki pendapatan di bawah UMR. Ibu-ibu yang terdata di Posyandu kenari 1 juga merupakan ibu-ibu yang terkadang tidak bekerja dan memiliki pendidikan yang rendah. Wilayah ini juga memiliki pemukiman padat yang dangan populasi yang tinggi. Hal ini terkadang menyulitkan untuk memastikan kebersihan di wilayah tersebut. Berdasarkan latar belakang permasalahan tersebut, penting rasanya untuk melakukan pendekatan terhadap orang tua di wilayah tersebut untuk meningkatkan pemahaman mengenai pentingnya perilaku diet dan kualitas hidup anak dengan cara melakukan pemantauan terus menerus, sehingga kita dapat memprofilkan masalah kesehatan anak dan mencegahnya (Muhaimin, 2010). Dengan begitu orangtua akan menjadi lebih peduli dan memiliki control yang lebih terhadap perkembangan anak. Usia penduduk di wilayah Posyandu Kenari 1 ini juga terdata banyak yang memilki anak usia dibawah 12 tahun di satu kartu keluarga. Posyandu Kenari 1 berada di Jl. Menvo, Tegal Alur, Kalideres. Karena pemukimannya padat, banyak sekali rumah di daerah ini yang memiliki akses jalan keci dengan selokan di pinggir yang sering berwarna hitam akibat limbah rumah tangga disana. Selain itu sering sekali berbau tidak enak.

Berdasarkan permasalahan tersebut beberapa solusi kegiatan akan dilaksanakan dalam kegiatan pengabdian masyarakat ini seperti mengadkaan penyuluhan mengenai definisi dan pentingnya kualitas hidup anak. Serta dilakukan juga penyuluhan mengenai diet sehat praktis anak yang akan membuka pandangan ibu yang memiliki anak di sekitar wilayah tempat pelaksanaan kegiatan bahwa diet sehat pada anak akan mempengaruhi kualitas hidup anak tersebut.

\section{Metode Pelaksanaan}

1. Tahapan Persiapan

Untuk kelancaran proses pelaksanaan, dilakukan terlebih dahulu sosialisasi dengan pihak terkait seperti puskesmas Kalideres, Posyandu Kenari 1 beserta ibu-ibu yang terdaftar di Posyandu tersebut yang memiliki anak usia 6-12 tahun. Tahapan ini ingin memastikan bahwa semua pihak terkait dan mitra bisa berkomitmen dalam mensukseskan pengabdian masyarakat ini.

\section{Tahapan Pelaksanaan}

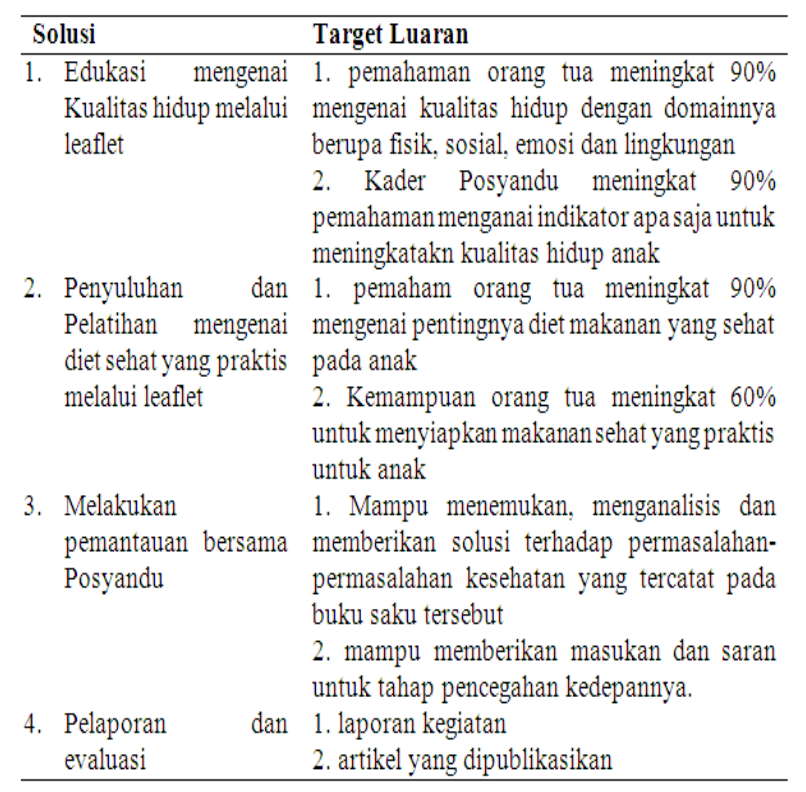

Materi pelatihan yang diberikan:

1. Edukasi Kualitas hidup

Materi : Definisi kualitas hidup, domain kualitas hidup, dampak kualitas hidup dimasa yang akan datang, cara menghitung kualitas hidup

2. Penyuluhan dan Pelatihan mengenai diet sehat yang praktis

Materi : definisi diet sehat anak, bahaya diet tidak sehat dan penjabaran nutrisi di setiap komponen item makan. Penjelasan mengenai menu sehat dan cara membuatnya. 
3. Tahapan Evaluasi dan Tahapan Pencapaian dan keberlanjutan Program

Tahapan ini dilaksanakan via media whatsapp dengan kepala posbindu untuk memastikan bahwa pengetahuan mengenai kualitas hidup anak dan diet sehat praktis ini selalu diberikan kepada ibu yang memiliki balita di Kawasan Posbindu tersebut.

\section{Hasil dan Pembahasan}

Pelaksanaan pengabdian masyarakat dilaksanakan tanggal 11 Mei 2020 dengan tujuan peningkatan pengetahuan mengenai mengonsumsi makanan sehat dengan sasaran Ibu yang memiliki anak sekolah. Pelaksanaan pengabdian masyarakat ini dilakukan dengan penyuluhan berupa penyebaran leaflet yang berisikan materi mengenai kualitas hidup anak dan diet sehat berkualitas. Metode ini dipilih seusia kondisi pandemic Covid-19 yang melanda seluruh dunia. Pemberian leaflet ini bertujuan untuk mengurangi kontak fisik sehingga mengurangi risiko dlaam penyebaran penyakit menular. Setelah penjelasan yang dilakukan menggunakan leaflet oleh Dosen Program Studi Kesehatan Masyarakat Gisely Vionalita SKM. M.Sc dan dibantu beberapa kader dan staf Puskemas Kalideres di Posyandu Kenari I. Pelaksanaan dimulai dengan mendatangi Kepala Puskesmas Kalideres dan kemudian pengabdian dilakukan di Posyandu Kenari 1 dengan melibatkan 50 ibu sebagai peserta. Pelaksanaan dimulai pada tanggal 11 Mei, namun dilanjutkan hingga tanggal 25 mei 2020, dikarenakan kondisi pandemic yang menyebabkan kurangnya jumlah pasien yang datang ke Puskesmas kalideres. Setelah penyuluhan menggunakan leaflet, maka dilakukan evaluasi menggunakan kuesioner feedback yang akan diisi oleh setiap peserta.

Berikut leaflet yang digunakan sebagai media penyuluahn di pengabdian masyarakat ini:

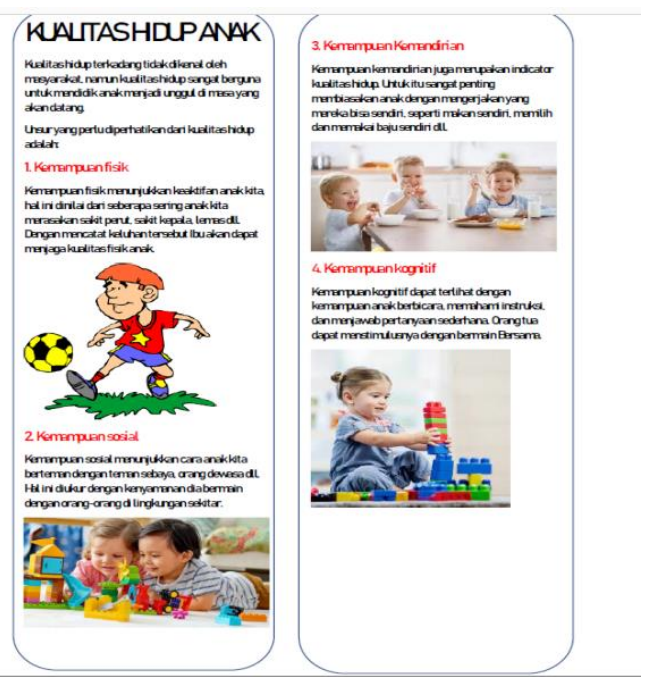

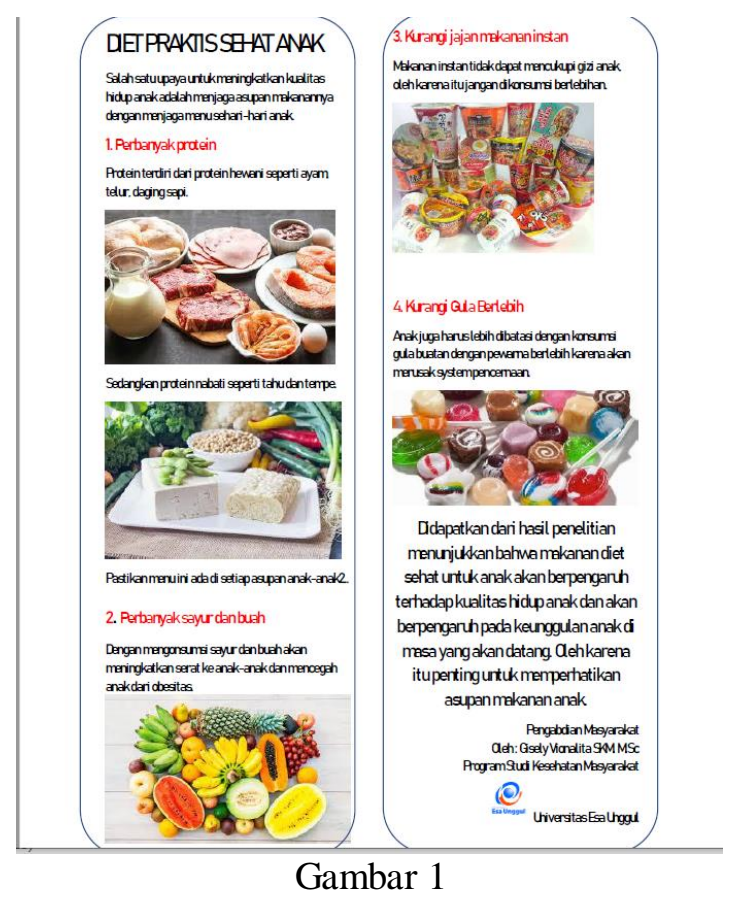

Leaflet Materi Penyuluhan

Peserta terlihat antusias terhadap topik ini. Banyak respon positif yang diberikan oleh ibu khususnya ketika menjelaskan kandungan makanan yang biasa mereka konsumsi dan dijual di sekitar lingkungan rumah.

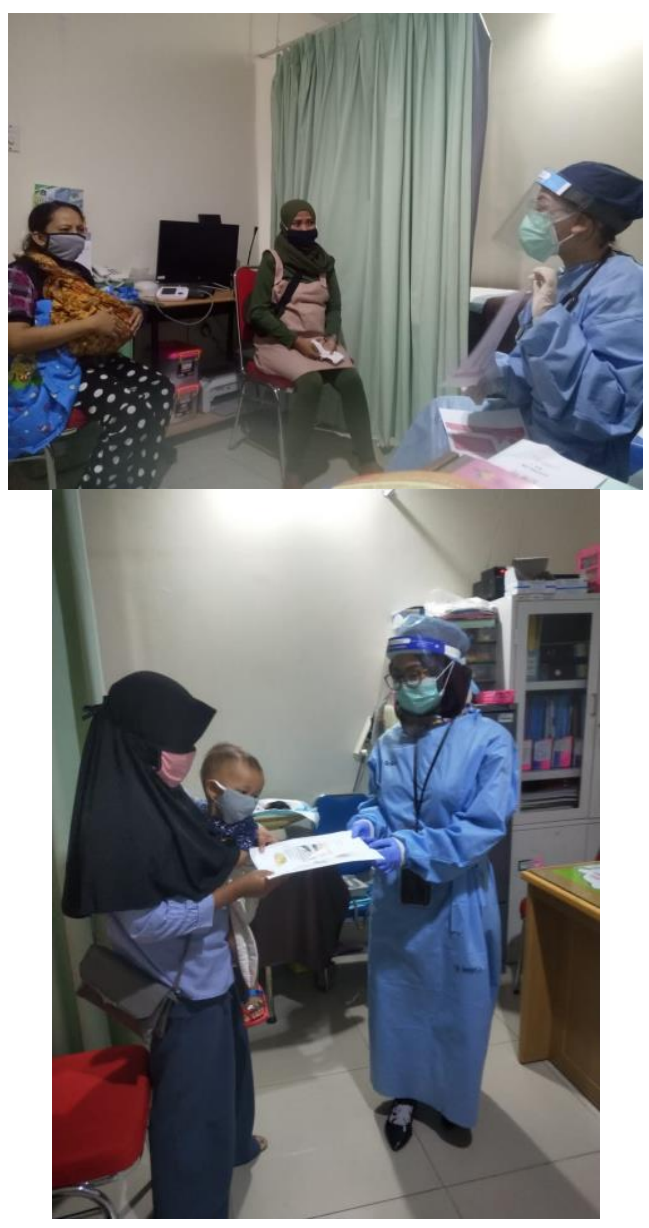




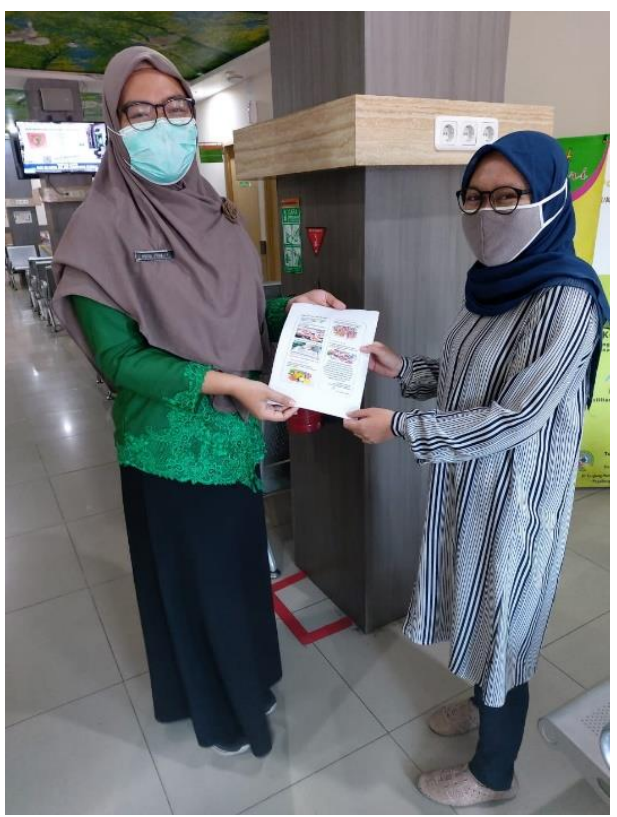

Gambar 2.

Pelaksanaan Penyuluhan dengan leaflet

Pengabdiam masyarakat ini ingin menitikberatkan informasi mengenai pentingnya menjaga kualitas hidup yang dijelaskan dengan berbagai macam indicator dibawah ini. Kualitas hidup terkadang tidak dikenal oleh masyarakat, namun kualitas hidup sangat berguna untuk mendidik anak menjadi unggul di masa yang akan datang.Unsur yang perlu diperhatikan dari kualitas hidup adalah: (1) Kemampuan fisik, Kemampuan fisik menunjukkan keaktifan anak kita, hal ini dinilai dari seberapa sering anak kita merasakan sakit perut, sakit kepala, lemas dll. Dengan mencatat keluhan tersebut Ibu akan dapat menjaga kualitas fisik anak; (2) Kemampuan sosial, Kemampuan sosial menunjukkan cara anak kita berteman dengan teman sebaya, orang dewasa dll. Hal ini diukur dengan kenyamanan dia bermain dengan orang-orang di lingkungan sekitar; (3) Kemampuan Kemandirian, Kemampuan kemandirian juga merupakan indicator kualitas hidup. Untuk itu sangat penting membiasakan anak dengan mengerjakan yang mereka bisa sendiri, seperti makan sendiri, memilih dan memakai baju sendiri dll; (4) Kemampuan kognitif, Kemampuan kognitif dapat terlihat dengan kemampuan anak berbicara, memahami instruksi, dan menjawab pertanyaan sederhana. Orang tua dapat menstimulusnya dengan bermain Bersama.

Selain kualitas hidup anak, pengabdian masyarakat ini juga menekankan mengenai pengetahuan Diet Praktisehat Anak. Dimana topik ini akan menjelaskan mengenai kandung-kandungan gizi anak yang dibutuhkan delam perkembangan dan pertumbuhan anak sekolah.

Salah satu upaya untuk meningkatkan kualitas hidup anak adalah menjaga asupan makanannya dengan menjaga menu sehari-hari anak seperti : (1) Perbanyak protein (2) perbanyak sayur, (3) Kurangi jajan makanan istan tidak sehat, (4) kurangi gula berlebih.

Setelah penyampaian materi di penyuluhan, siswa diminta untuk menjawab 5 pertanyaan dengan pilihan ganda untuk memastikan pemahaman mereka mengenai makanan sehat, manfaat dan upaya untuk mengonsumsi makanan sehat. Hasil yang didapatkan dari kuesioner tersebut seperti berikut:

Tabel 3.

Hasil pengukuran pemahanan siswa-siswi SD N Pegadungan 2 Pagi

\begin{tabular}{llll}
\hline No. & $\begin{array}{l}\text { Item } \\
\text { Pertanyaan }\end{array}$ & Benar & Salah \\
\hline 1 & $\begin{array}{l}\text { Definisi kualitas } \\
\text { hidup } 84 \%\end{array}$ & $16 \%$ \\
2 & $\begin{array}{l}\text { Definisi dan } 92 \% \\
\text { Manfaat }\end{array}$ & $8 \%$ \\
3 & $\begin{array}{l}\text { makanan sehat } \\
\text { Kandungan } \\
\text { makanan yang } \\
\text { dibutuhkan }\end{array}$ & $12 \%$ \\
\hline
\end{tabular}

Hasil profil mengenai pemahaman Ibu-ibu yang memiliki anak usia sekolah tersebut menunjukkan angka yang tinggi dan dapat diartikan bahwa peserta cukup memberikan antusias mereka dan sangat mencermati isi dari penyuluhan tersebut. Pemahaman materi tersebut menunjukkan adanya peningkatan pengetahuan mengenai kualitas hidup dan diet sehat praktis anak. Hal ini yang dapat menjadi landasan upaya perubahan perilaku mengonsumsi makanan sehat dan akan berpengaruh pada kualitas hidup anak. Dengan pelaksanaan kegiatan ini, diharapkan kedepannya terdapat pemantauan berkala dan kebijakan dari puskesmas mengenai pendekatan ke setiap sekolah untuk menduung program diet sehat parktis untuk anak sekolah disana. Sehingga dapat terwujud anak sekolah yang sehat dan memiliki kualitas hidup yang baik.

\section{Kesimpulan}

Kegiatan pengabdian masyarakat ini memberikan peningkatan pengetahuan mengenai kualitas hidup anak sekolah dan diet sehat praktis anak dengan memberikan penyuluhan berupa leaflet kepada ibu yang hadir di posyandu Kenari dan Puskesmas Kalideres, Jakarta Barat. Kegiatan ini dapat terlaksana dengan optimal dan lancar. Terlihat dari hasil feedback dari peserta yang menunjukkan respon positif dan menyatakan mendapatkan informasi yang sebelumnya mereka belum ketahui. Hasil pengukuran pengetahuan ibu-ibu didapatkan rata-rata lebih dari 85\% mengetahui mengenai definisi kualitas hidup, manfaat dan upaya 
mengonsumsi makanan sehat dan itu semua didapatkan setelah pelaksanaan pengabdian masyarakat ini. Peningkatan pengetahuan ini penting untuk merubah perilaku sehat pada siswa-sisiwi sekolah tersebut untuk tercapai kualitas hidup siswa yang baik.

\section{Daftar Pustaka}

Aprillia, B. A., \& Aprillia, B. A. (2011). Faktor yang berhubungan dengan pemilihan makanan jajanan pada anak sekolah dasar (Doctoral dissertation, Diponegoro University).WorldHealthOrganitation.

(201). Introducing The WHOQOL Instruments.

http://depts.washington.edu/seaqol/WHOQ OL-BREF.World Health Organitation. Di Unduh Tanggal 27 Oktober2017 Jam 22:49.

Cahanar, P., \& Suhanda, I. (2006). Makan sehat hidup sehat. Penerbit Buku Kompas.DepartemenKesehatanRepublikInd onesia.(2013).HasilRisetKesehatan.

Fitriani, N. L., \& Andriyani, S. (2015). Hubungan Antara Pengetahuan dengan Sikap Anak Usia Sekolah Akhir (10-12 Tahun) Tentang Makanan Jajanan di SD Negeri II Tagog Apu Padalarang Kabupaten Bandung Barat Tahun 2015. JURNAL PENDIDIKAN KEPERAWATAN INDONESIA, 1(1), 7-26.

Kemenkes RI. Situasi Diare di Indonesia. 2011 (diunduh 24 februari 2012). Tersedia.

Mohammad, A., \& Madanijah, S. (2015). Konsumsi buah dan sayur anak usia sekolah dasar di Bogor. Jurnal Gizi dan Pangan, 10(1).

Suci, E. S. T. (2009). Gambaran perilaku jajan murid sekolah dasar di Jakarta. Jurnal Psikobuana, 1(1), 29-38.Atun.(2010). Diabetes Melitus: Memahami, Mencegah, Dan MerawatPenderita PenyakitGula. Bantul: Kreasi Wacana.

WHO. Diarrhoeal disease. 2009 (diunduh 25 Februari 2012). Tersedia dari URL: HYPERLINK

http://www.who.int/mediacentre/facsheets/fs 330/en/ 66. http://jurnal.fk.unand.ac.id Jurnal Kesehatan Andalas. 2013; 2(2). 